\title{
MENINGKATKAN KEMAMPUAN BERFIKIR KRITIS SISWA MELALUI PENERAPAN PENDEKATAN PEMBELAJARAN KONTEKSTUAL DI SEKOLAH DASAR KABUPATEN BANDUNG BARAT
}

\author{
${ }^{1)}$ Agni Muftianti1, ${ }^{2)}$ Sylvia Rabbani, ${ }^{3)}$ Gita Anisa Solihat, ${ }^{4)}$ Nurhayani, ${ }^{5}$ Fitriyani Via Ardrya \\ Garini, ${ }^{6}$ Ressa Rizkita Ruswina \\ 1) sylviarabbani@gmail.com, ${ }^{2)}$ agnimuftianti@gmail.com, ${ }^{3)}$ githaanisa@gmail.com \\ ${ }^{4)}$ yoneycute@gmail.com,${ }^{5)}$ viarafitri@gmail.com, ${ }^{6}$ rressa03@gmail.com
}

\section{1, 2, 3, 4, 4, 5, 6)Program Studi PGSD, Fakultas Ilmu Pendidikan, IKIP Siliwangi}

\begin{abstract}
ABSTRAK
Masalah utama penelitian ini adalah kurangnya kemampuan berfikir kritis siswa Sekolah Dasar di Kabupaten Bandung Barat. Secara umum, tujuan jangka panjang program penelitian ini adalah meningkatkan kemampuan berfiikir kritis siswa melalui penerapan pendekatan pembelajaran kontekstual di Sekolah Dasar Kabupaten Bandung Barat. Secara khusus, target khusus yang ingin dicapai sebagai berikut: : (1). Memberikan pembelajaran yang menyenangkan untuk meningkatkan kemampuan berfikir kritis siswa SD; (2). Memberikan pembelajaran yang menyenangkan dan bisa menginspirasi siswa dan guru-guru SD; (3). Memberikan cara-cara belajar menyenangkan dan bermakna melalui pendekatan pembelajaran kontekstual. Metode yang akan dipakai adalah Kuasi Eksperimen dengan pendekatan kuantitatif dan kualitatif. Subjek penelitian adalah siswa kelas V di 2 Sekolah Dasar di Kabupaten Bandung Barat yaitu SDN Ciburuy 1 dan SDN Ciburuy 2.
\end{abstract}

Kata Kunci: pendekatan pembelajaran kontekstual, Kemampuan Berfikir Kritis.

\begin{abstract}
The main problem of this research is the lack of critical thinking ability of elementary school students in West Bandung regency. In general, the long-term goal of this research program is to improve students' critical thinking ability through the application of Contextual Teaching and Learning Approach in elementary school of West Bandung regency. In particular, the specific targets to be achieved are as follows: (1). Provide a fun learning to improve students' critical thinking skills; (2). Providing fun learning and inspiring elementary school students and teachers; (3). Providing fun and meaningful learning methods through Contextual Teaching and Learning Approach. The method to be used is Quasi Experiment with quantitative and qualitative approach. The subjects of the study were $\mathrm{V}$ grade students in 2 elementary schools in West Bandung regency, SDN Kamulyaan 1 and SDN Kamulyaan 2.
\end{abstract}

Keywords: Contextual Teaching and Learning Approach, Critical Thinking Ability.

\section{A. PENDAHULUAN}

Salah satu keterampilan yang harus dikuasai oleh anak usia sekolah dasar adalah keterampilan sosial. Karena pada dasarnya manusia memerlukan orang lain untuk melangsungkan kehidupannya yang sering kita sebut bahwa manusia itu makhluk sosial. Maka dari itu untuk bersosialisasi dengan sesama, manusia harus memiliki keterampilan sosial, bagaimana cara berkomunikasi, bekerjasama, berkreativitas, dan menjadi warga negara yang baik merupakan beberapa keterampilan sosial yang harus dikuasai agar dalam kehidupan bermasyarakat kita dapat diterima dengan baik. Selain itu dalam era globalisasi seperti saat ini diperlukan keterampilan sosial yang harus dikuasai sejak dini agar dapat bersaing di era globalisasi pada abad ke 21 ini. Ada beberapa keterampilan sosial yang harus dimiliki anak untuk menghadapi globalisasi di abad ke 21 menurut Griffin (2012: 8) yaitu:
Creativity And Innovation; Critical Thinking, Problem Solving, And Decision Making ; Learning To Learn, Metacognition; Communication; Collaboration, Teamwork; Information Literacy; ICT Literacy; Elaboration Of Key Concepts Of Ict Literacy Based On Ets Framework; Citizenship, Local And Global; Life And Career; Personal And Social Responsibility.

Seperti pernyataan dari Griffin diatas yaitu untuk menghadapi era globalisasi di abad ke 21 kemampuan berpikir kritis harus dimiliki siswa. Dalam upaya memecahkan masalah-masalah pada kehidupan sehari-hari, kemampuan berpikir seseorang merupakan kemampuan yang sangat berpengaruh untuk menentukan keberhasilan orang tersebut dalam menghadapi globalisasi pada abad ke 21 . Keterampilan berpikir kritis 
adalah salah satu keterampilan berpikir tingkat tinggi. Menurut Ennis dalam Fisher (2009: 4) berpikir kritis adalah pemikiran yang masuk akal dan reflektif yang berfokus untuk memutuskan apa yang mesti dipercaya atau dilakukan. Sedangkan menurut John Dewey dalam Fisher (2009: 2) mendefinisikan berpikir kritis sebagai proses yang persistent (terus menerus), dan teliti mengenai suatu asumsi.

Namun kenyataan di lapangan menunjukkan bahwa kemampuan berpikir kritis siswa belum optimal, rendahnya kemampuan siswa berpikir kritis diduga karena selama ini guru tidak berusaha menggali pengetahuan dan pemahaman siswa tentang berpikir kritis. Dari hasil pengamatan dan pengalaman penulis selama proses pembelajaran di SD Kabupaten Bandung Barat, selama ini guru hanya melaksanakan pembelajaran secara prosedural, mengerjakan soal-soal latihan, tanpa memberi kesempatan siswa untuk berpikir kritis akibatnya siswa tidak menemukan makna dari apa yang dipelajari tersebut.

Agar terjadi pengkontruksian pengetahuan secara bermakna, guru haruslah melatih siswa agar berpikir secara kritis dalam menganalisis maupun dalam memecahkan suatu permasalahan. Siswa yang berpikir kritis adalah siswa yang mampu mengidentifikasi, mengevaluasi, dan mengkontruksi argumen serta mampu memecahkan masalah dengan tepat (Spliter 1991, dalam Redhana 2003: 12-13). Siswa yang berpikir kritis akan mampu menolong dirinya atau orang lain dalam memecahkan permasalahan yang dihadapi.

Salah satu usaha yang dapat dilakukan adalah proses pembelajaran yang memberikan penekanan lebih seperti memberikan contoh secara nyata, melibatkan siswa untuk ikut memberikan tanggapan sertas solusi yang akan membuiat siswa lebih mudah memahami materi dan dapat mengaplikasikan dalam kehidupan sehari-hari di lingkungan rumah, sekolah dan masyarakat. Model pembelajaran yang dianggap dapat meningkatkan keterampilan sosial khusunya keterampilan berfikir kritis adalah pendekatan pembelajaran kontekstual, untuk itu pada penelitian ini akan mencoba menerpakan pendekatan pembelajaran kontekstual untuk mengetahui bagaimana pengaruhnya terhadap peningkatan keterampilan berfikir kritis.

\section{B. KAJIAN TEORI DAN METODE 1. Berpikir Kritis}

Berpikir ialah kemampuan yang menghubungkan hubungan-hubungan antara pengetahuanpengetahuan kita dengan apa yang dialami atau yang dibayangkan. Berfikir juga merupakan suatu tindakan yang mempertimbangkan baik tidaknya tindakan yang akan kita ambil sebagai jalan pikiran seseorang. Berpikir merupakan suatu proses dialektis, artinya selama kita berpikir, pikiran kita mengadakan tanya jawab pikiran kita. Untuk dapat meletakkan hubungan-hubungan antara pengetahuan kita dengan tepat". Menurut Gieles menyatakan bahwa:

"Berpikir adalah berbicara dengan dirinya sendiri dalam batin, yaitu mempertimbangkan, merenungkan, menganalisis, membuktikan sesuatu, menunjukkan alasan-alasan, menarik kesimpulan, meneliti sesuatu jalan pikiran, mencari bagaimana berbagai hal itu berhubungan satu sama lain".

Sedangkan menurut Plato (dalam Suryabrata: 2002 :12): "Berpikir itu adalah berbicara dalam hati".

Berpikir kritis adalah kemampuan berfikir dengan menggunakan berbagai proses analisis dan evaluasi mengenai fakta dan gagasan yang ada dalam mendapatkan beberapa gagasan dan mempertahankan gagasan tersebut kemudian membuat perbandingan. Menurut pendapat para ahli, definisi berpikir kritis itu bermacam-macam. Berikut dikemukakan beberapa pendapat tentang pengertian berpikir kritis. Menurut Ennis dalam Fisher (2009: 4) berpikir kritis adalah pemikiran yang masuk akal dan reflektif yang berfokus untuk memutuskan apa yang mesti dipercaya atau dilakukan. Sedangkan menurut John Dewey dalam Fisher (2009: 2) mendefinisikan berpikir kritis sebagai proses yang persistent (terus menerus), dan teliti mengenai suatu asumsi.

\section{Pembelajaran Kontekstual}

Pembelajaran kontekstual pada hakehatnya merupakan suatu pembelajaran yang berusaha mengaitkan aktifitas kehidupan sehari-hari, agar pembelajaran berjalan lebih produktif. Pendektan pembelajaran kontekstual dapat dilaksanakan di SD pada kelas dan topik manapun yang tentu saja disesuaikan dengan kebutuhan siswa. Menurut Nurhadi (2002), Model pembelajaran kontekstual merupakan salah satu model yang merupakan konsep belajar yang dapat membantu guru mengaitkan antara materi yang diajarkan dengan 
situasi dunia nyata siswa dan mendorong siswa membuat hubungan antara pengetahuan yang dimilikinya dengan penerapannya dalam kehidupan mereka sebagai anggota keluarga dan masyarakat.

\section{Metodologi}

Penelitian ini dilaksanakan di SDN Ciburuy 01 dan SDN Ciburuy 02 yang beralamatkan di Kabupaten Bandung Barat. Pemilihan lokasi penelitian berdasarkan pada pertimbangan bahwa kedua sekolah tersebut merupakan sekolah yang mempunyai prestasi yang berbeda meskipun masih dalam satu lingkup sekolah yang berdekatan jaraknya. Serta dijadikan sebagai penelitian untuk mengungkapkan apa yang telah diterapkan pada sekolah masing-masing.

Metode penelitian ini menggunakan pendekatan kuantitatif yaitu jenis penelitian yang menggunakan rancangan penelitian berdasarkan prosedur statistik atau dengan cara lain dari kuantifikasi untuk mengukur variabel penelitiannya. Adapun metode kuantitatif yang digunakan adalah metode eksperimen, yang mana dalam penelitian ini menggunakan eksperimen kuasi atau eksperimen semu.

Penelitiaan ini bertujuan untuk mencari pengaruh dari suatu perlakuan berupa penerapan pendekatan pembelajaran kontekstual dalam meningkatkan kemampuan berfikir kritis siswa di Sekolah Dasar Kabupaten Bandung Barat, dengan membandingkan pemahaman peserta didik sebelum menggunakan pendekatan pembelajaran kontekstual dan sesudah menggunakan pendekatan pembelajaran kontekstual. Atau dengan cara membandingkan kelas yang diajar menggunakan pendekatan pembelajaran kontekstual dengan kelas yang diajar dengan menggunakan pendekatan pembelajaran secara konvensional.

Menurut Syamsudin, Damaianti, 2009, hlm. 162. (dalam Pebriana, 2014) rancangan eksperimental kuasi memiliki kesepakatan praktis antara eksperimen kebenaran dan sikap asli manusia terhadap bahasa yang kita teliti. Rancangan eksperimen kuasi atau eksperimen semu mengontrol banyak variabel dan batasan dari jenis interpretasi yang kita lakukan untuk mengetahui sebab pengaruh pertautan dan membatasi kekuatan dari generalisasi pernyataan kita. Dalam rancangan ini, bentuk penelitian kuasi eksperimen dipandang relevan digunakan karena memiliki ciri-ciri yaitu: 1) pemecahan masalah yang aktual, 2) data yang dikumpulkan disusun, kemudian dijelaskan dan data tersebut dianalisis.

Dalam membandingkan hasil penelitian variabel eksperimen dan variabel kontrol, peneliti menggunakan statistik deskriptif. Tujuannya agar gambaran pada data yang telah diperoleh menjadi lebih jelas baik bagi peneliti sendiri maupun bagi orang lain yang berminat untuk mengetahuinya. Menurut Sugiyono (2013, hlm. 29) statistik deskriptif adalah statistik yang berfungsi untuk mendeskripsikan atau memberi gambaran terhadap obyek yang diteliti melalui data sampel atau populasi sebagaimana adanya, tanpa melakukan analisis dan membuat kesimpulan yang berlaku untuk umum.

\section{HASIL PENELITIAN PEMBAHASAN}

Pengolahan data hasil tes kemampuan berfikir kritis berdasarkan pada data pretes dan postes pada masing-masing kelas. Data-data tersebut untuk masing-masing kelas dapat dilihat pada lampiran.

\section{Kelas Eksperimen}

Berdasarkan rumusan masalah nomer 1, hipotesis pada penelitian yang harus diuji adalah "terdapat perbedaan kemampuan berpikir kritis pada siswa yang menggunakan model pembelajaran kontekstual pada pengukuran awal (pretes) dan pengukuran akhir (postes)". Skor pretes kemampuan berfikir kritis diperoleh dari tes yang diberikan sebelum pembelajaran diterapkan di kelas eksperimen dan kelas kontrol. Analisis uji kesamaan rataan kemampuan berfikir kritis antara siswa pada kelas eksperimen dan kelas control bertujuan untuk memperlihatkan bahwa tidak terdapat perbedaan yang signifikan antara kelas eksperimen dan kelas kontrol. Sebelum melakukan uji dua rata-rata, terlebih dahulu dilakukan uji normalitas dan homogenitas variansi. Adapun langkah-langkah pengujian hipotesis ini adalah sebagai berikut:

\section{a. Analisis data skor pretest dan postes kemampuan berfikir kritis kelas eksperimen}

Statistik deskriptif skor pretest dan postes kemampuan berfikir kritis kelas eksperimen disajikan dalam tabel 4.1 dan tabel 4.2 berikut ini: 
Tabel 4.1

Statistik deskriptif skor pretest kemampuan berfikir kritis kelas eksperimen

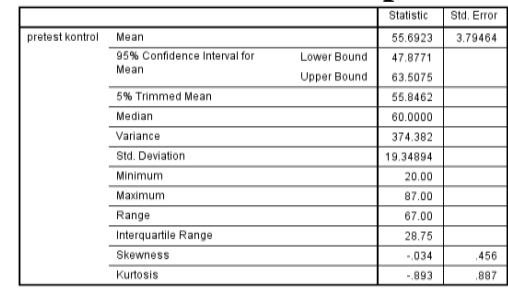

Skor maksimal ideal $=100$

Tabel 4.2

Statistik deskriptif skor postes kemampuan berfikir kritis kelas eksperimen

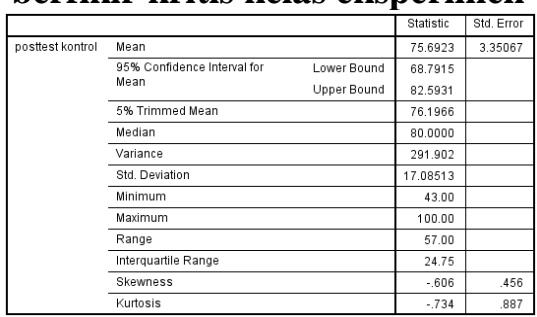

Skor maksimal ideal $=100$

Berdasarkan data pada tabel 4.1 dan tabel 4.2 jumlah sampel adalah eksperimen 26 siswa. Pada rata-rata skor postest kemampuan berfikir kritis kelas ekperimen memiliki nilai rata-rata 75,69 dan lebih tinggi dari rata-rata skor pretes yang hanya memiliki nilai rata-rata 55,69. Selisih ratarata antara kedua skor adalah 20,00 yang apabila dikonversikan dalam bentuk presentase pencapaian skor postes adalah $75,69 \%$ atau $20,00 \%$ lebih tinggi dari pencapaian skor pretes yang hanya memperoleh. 55,69\%. Perbedaan pencapaian antara skor pretes dan skor postes sudah terlihat tinggi. Namun masih perlu dilakukan pengujian berikutnya. Pengolahan data skor pretest dan postes kemampuan berfikir kritis pada kelas ekperimen ini dimulai dengan cara melakukan uji normalitas.

Tujuan dari uji normalitas adalah untuk melihat data yang diperoleh itu berdistribusi normal atau tidak. Jika normal, maka dapat dilanjutkan pada uji homogenitas untuk melihat keseragaman varians. (Riduwan, 2003, halaman 184), dan yang terakhir dilakukan uji perbedaan rata-rata dari dua kelas untuk melihat perbedaan kemampuan awal dari kedua kelas tersebut. Adapun penjelasan mengenai pengolahan data tersebut adalah sebagai berikut:

\section{b. Uji normalitas data skor pretes kemampuan} berfikir kritis di kelas ekperimen

Uji normalitas skor pre-test kemampuan berfikir kritis kedua kelas menggunakan uji Shapiro-Wilk dengan tujuan untuk mengetahui apakah data dari masing-masing sampel itu berdistribusi normal atau tidak. Uji normalitas ini menggunakan bantuan software SPSS 23.0 for windows.

Ada pun bentuk Hipotesis Uji Normalitas Skor pretes Kemampuan Berfikir Kritis Siswa Kelas Eksperimen :

$\mathrm{H}_{0}$ : Skor pre-test kemampuan berfikir kritis siswa kelas eksperimen berdistribusi normal.

$\mathrm{H}_{1}$ : Skor pre-test kemampuan berfikir kritis siswa kelas eksperimen tidak berdistribusi normal.

Kriteria yang digunakan untuk menolak dan menerima $\mathrm{H}_{0}$ berdasarkan $\mathrm{P}$-value adalah $\mathrm{H}_{0}$ ditolak jika nilai signifikansi P-value $<\alpha$ (taraf signifikansi 0,05) dan $\mathrm{H}_{0}$ diterima jika nilai signifikansi $\mathrm{P}$-value $\geq \alpha$. Dari hasil perhitungan dengan menggunakan software SPSS 23.0 for windows, diperoleh hasil uji normalitas pada tabel 4.3 sebagai berikut:

\section{Tabel 4.3}

Uji Normalitas Skor Pre-test Kemampuan Berfikir Kritis Kelas Eksperimen

\begin{tabular}{|l|r|r|r|r|r|c|}
\hline \multirow{2}{*}{} & \multicolumn{3}{|c|}{ Kolmogorov-Smirnov $^{\text {a }}$} & \multicolumn{3}{c|}{ Shapiro-Wilk } \\
\cline { 2 - 7 } & Statistic & \multicolumn{1}{c|}{ df } & \multicolumn{1}{c|}{ Sig. } & Statistic & \multicolumn{1}{c|}{ df } & Sig. \\
\hline pretest kontrol & .127 & 26 & $.200^{*}$ & .953 & 26 & .276 \\
\hline
\end{tabular}

Tabel 4.3 menunjukkan bahwa skor pre-test kemampuan berfikir kritis siswa kelas eksperimen untuk uji normalitas Kolmogorof-Smirnov memiliki skor P-value $(\mathrm{Sig})=0,200>0.05$ sehingga $\mathrm{H}_{0}$ diterima pada taraf signifikansi = 0.05 . Artinya, skor pre-test kemampuan berfikir kritis kelas ekperimen ini berdistribusi normal.

\section{c. Uji normalitas data skor postes kemampuan}

berfikir kritis di kelas ekperimen

Ada pun bentuk Hipotesis Uji Normalitas Skor postes Kemampuan Berfikir kritis Siswa Kelas Eksperimen :

$\mathrm{H}_{0}$ : Skor post-test kemampuan berfikir kritis siswa kelas eksperimen berdistribusi normal.

$\mathrm{H}_{1}$ : Skor post-test kemampuan berfikir kritis siswa kelas eksperimen tidak berdistribusi normal.

Kriteria yang digunakan untuk menolak dan menerima $\mathrm{H}_{0}$ berdasarkan $\mathrm{P}$-value adalah $\mathrm{H}_{0}$ ditolak jika nilai signifikansi P-value $<\alpha$ (taraf signifikansi 0,05) dan $\mathrm{H}_{0}$ diterima jika nilai signifikansi $\mathrm{P}$-value $\geq \alpha$. Dari hasil perhitungan dengan menggunakan software SPSS 23.0 for windows, diperoleh hasil uji normalitas pada tabel 4.9 sebagai berikut: 
Tabel 4.4

Uji Normalitas Skor Postest Kemampuan Berfikir Kritis Kelas Eksperimen

\begin{tabular}{|c|r|r|r|r|r|c|}
\hline & \multicolumn{3}{|c|}{ Kolmogorov-Smirnov } & \multicolumn{3}{|c|}{ Shapiro-Wilk } \\
\cline { 2 - 7 } & Statistic & \multicolumn{1}{|c|}{ df } & \multicolumn{1}{c|}{ Sig. } & Statistic & \multicolumn{1}{c|}{ df } & \multicolumn{1}{c|}{ Sig. } \\
\hline posttest kontrol & .166 & 26 & .065 & .922 & 26 & .050 \\
\hline
\end{tabular}

Tabel 4.9 menunjukkan bahwa skor post-test kemampuan berfikir kritis siswa kelas eksperimen untuk uji normalitas Kolmogorof-Smirnov memiliki skor P-value $(\mathrm{Sig})=0,065>0.05$ sehingga $\mathrm{H}_{0}$ diterima pada taraf signifikansi = 0.05 . Artinya, skor post-test kemampuan berfikir kritis kelas eksperimen ini berdistribusi normal. Berdasarkan hasil uji normalitas KolmogorofSmirnov kedua skor kemampuan berfikir kritis pada kelas eksperimen yang berdistribusi normal. Sehingga pengolahan data dapat dilanjutkan dengan uji homogenitas.

d. Uji homogenitas data skor pretes dan postes kemampuan berfikir kritis di kelas ekperimen

Uji homogenitas data skor pretes dan postes kemampuan berfikir kritis di kelas ekperimen dilakukan karena skor kedua skor berdistribusi normal. Ada pun bentuk hipotesis dari uji homogenitas data ini adalah sebagai berikut:

$\mathrm{H}_{0}$ : Skor pretest dan potes kemampuan berfikir kritis kelas eksperimen bervariansi homogen.

$\mathrm{H}_{1}$ : Skor pretest dan potes kemampuan berfikir kritis kelas eksperimen bervariansi tidak homogen.

$\mathrm{H}_{0}$ ditolak jika nilai signifikansi P-value $<\alpha$ (taraf signifikansi). $\mathrm{H}_{0}$ diterima jika nilai signifikansi $\mathrm{P}$ value $\geq \alpha$ (taraf signifikansi). Data hasil uji homogenitas menggunakan software SPSS 23.0 for windows dengan uji Levene dapat dilihat pada tabel 4.5 berikut ini:

\section{Tabel 4.5}

Uji Homogenitas Skor Pre-test dan Postest Kemampuan Berfikir kritis Kelas Eksperimen

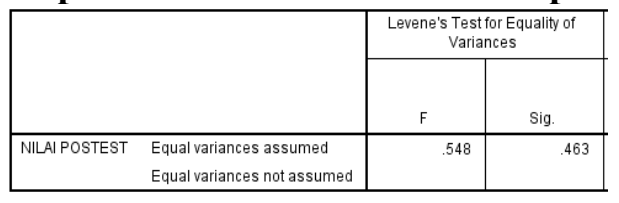

Tabel 4.5 menunjukkan bahwa hasil uji homogenitas skor pre-test kemampuan berfikir kritis siswa kedua kelas memiliki P-value (Sig) $0,463 \geq \alpha=0,05$ dengan demikian $\mathrm{H}_{0}$ ditolak pada taraf signifikansi $\alpha=0,05$. Artinya, skor pre-test kemampuan berfikir kritis kelas eksperimen dan kontrol bervariansi homogen. d. Uji perbedaan dua rata-rata data skor pretes dan postes kemampuan berfikir kritis di kelas ekperimen

Selanjutnya, dilakukan analisis data uji perbedaan rata-rata karena data kedua skor pada kelas eksperimen berdistribusi normal dan bervariansi homogen, maka digunakan uji hipotesis dengan uji-t (Paired-sample t test) dengan asumsi kedua varians homogen (Equal Variance Assumed). Untuk menguji perbedaan dua rata-rata masingmasing skor pretes dan postes di kelas eksperimen kemampuan berfikir kritis siswa dilakukan dengan menggunakan bantuan program komputer software SPSS 23.0 for windows. Hipotesis yang digunakan dalam uji-t adalah sebagai berikut:

$\mathrm{H}_{0}$ : Tidak terdapat perbedaan kemampuan berpikir kritis pada siswa yang menggunakan model pembelajaran kontekstual pada pengukuran awal (pretes) dan pengukuran akhir (postes).

$\mathrm{H}_{1}$ : Terdapat perbedaan kemampuan berpikir kritis pada siswa yang menggunakan model pembelajaran kontekstual pada pengukuran awal (pretes) dan pengukuran akhir (postes).

$\mathrm{H}_{0}$ ditolak jika nilai signifikansi $\mathrm{P}$-value $<\alpha$ (taraf signifikansi). $\mathrm{H}_{0}$ diterima jika nilai signifikansi $\mathrm{P}$ value $\geq \alpha$ (taraf signifikansi). Ada pun hasil uji-t ditunjukkan pada tabel 4.15 berikut ini:

Tabel 4.6

Analisis Uji-T Skor Pre-test dan Postes Kemampuan berfikir kritis kelas Eksperimen

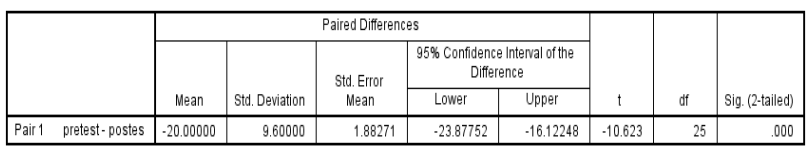

Tabel 4.6 menunjukkan hasil uji-t dengan skor Pvalue (Sig. 2 tailed) $=0,000$ pada taraf signifikansi $\alpha=0,05$ karena yang diuji dua arah sehingga 0,000 dibagi 2 hasilnya $=0,000<0,05=$ $\alpha$, kondisi demikian $\mathrm{H}_{0}$ ditolak artinya, terdapat perbedaan yang signifikan skor pre-test dan postes kemampuan kemampuan berfikir kritis siswa di kelas eksperimen.

\section{Kelas Kontrol}

Berdasarkan rumusan masalah nomer 2, hipotesis pada penelitian yang harus diuji adalah "terdapat perbedaan kemampuan berpikir kritis pada siswa yang menggunakan model pembelajaran konvensional pada pengukuran awal (pretes) dan pengukuran akhir (postes)". Skor pretes kemampuan berfikir kritis diperoleh dari tes yang diberikan sebelum pembelajaran diterapkan di 
kelas kontrol dan kelas kontrol. Analisis uji kesamaan rataan kemampuan berfikir kritis antara siswa di kelas kontrol pada pretest dan postes bertujuan untuk memperlihatkan bahwa tidak terdapat perbedaan yang signifikan. Sebelum melakukan uji dua rata-rata, terlebih dahulu dilakukan uji normalitas dan homogenitas variansi. Adapun langkah-langkah pengujian hipotesis ini adalah sebagai berikut:

a. Analisis data skor pretest dan postes kemampuan berfikir kritis kelas kontrol

Statistik deskriptif skor pretest dan postes kemampuan berfikir kritis kelas kontrol disajikan dalam tabel 4.7 dan tabel 4.8 berikut ini:

Tabel 4.7

Statistik deskriptif skor pretest kemampuan berfikir kritis kelas kontrol

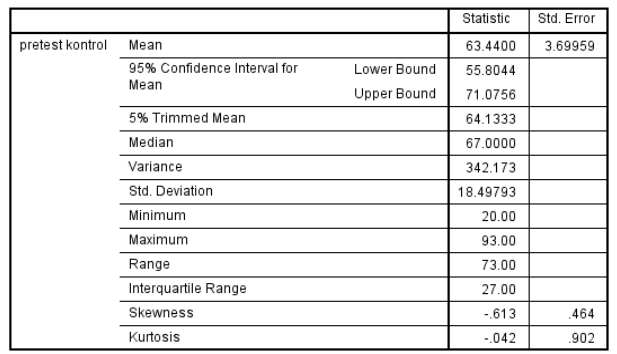

Skor maksimal ideal $=100$

Tabel 4.8

Statistik deskriptif skor postes kemampuan berfikir kritis kelas kontrol

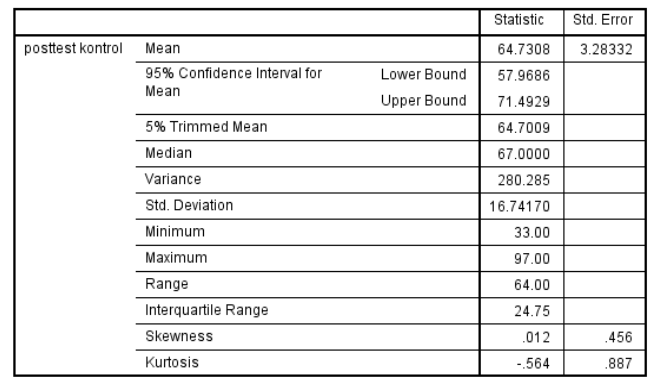

Skor maksimal ideal $=100$

Berdasarkan data pada tabel 4.7 dan tabel 4.8 jumlah sampel di kelas kontrol adalah 26 siswa. Pada rata-rata skor postest kemampuan berfikir kritis kelas kontrol memiliki nilai rata-rata 64,73 dan lebih tinggi dari rata-rata skor pretes yang hanya memiliki nilai rata-rata 63,44 . Selisih ratarata antara kedua skor adalah 1,29 yang apabila dikonversikan dalam bentuk presentase pencapaian skor postes adalah $64,73 \%$ atau $1,29 \%$ lebih tinggi dari pencapaian skor pretes yang hanya memperoleh. 63,44\%. Perbedaan pencapaian antara skor pretes dan skor postes sudah terlihat rendah. Namun masih perlu dilakukan pengujian berikutnya. Pengolahan data skor pretest dan postes kemampuan berfikir kritis pada kelas kontrol ini akan dilanjutkan dengan cara melakukan uji normalitas.

Tujuan dari uji normalitas adalah untuk melihat data yang diperoleh itu berdistribusi normal atau tidak. Jika normal, maka dapat dilanjutkan pada uji homogenitas untuk melihat keseragaman varians. (Riduwan, 2003, hal. 184), dan yang terakhir dilakukan uji perbedaan rata-rata dari dua kelas untuk melihat perbedaan kemampuan awal dari kedua kelas tersebut. Adapun penjelasan mengenai pengolahan data tersebut adalah sebagai berikut:

\section{b. Uji normalitas data skor pretes} kemampuan berfikir kritis di kelas kontrol Ada pun bentuk Hipotesis Uji Normalitas Skor pretes Kemampuan Berfikir Kritis Siswa Kelas Kontrol :

$\mathrm{H}_{0}$ : Skor pre-test kemampuan berfikir kritis siswa kelas kontrol berdistribusi normal.

$\mathrm{H}_{1}$ : Skor pre-test kemampuan berfikir kritis siswa kelas kontrol tidak berdistribusi normal.

Kriteria yang digunakan untuk menolak dan menerima $\mathrm{H}_{0}$ berdasarkan $\mathrm{P}$-value adalah $\mathrm{H}_{0}$ ditolak jika nilai signifikansi P-value $<\alpha$ (taraf signifikansi 0,05$)$ dan $\mathrm{H}_{0}$ diterima jika nilai signifikansi $\mathrm{P}$-value $\geq \alpha$. Dari hasil perhitungan dengan menggunakan software SPSS 23.0 for windows, diperoleh hasil uji normalitas pada tabel 4.3 sebagai berikut:

\section{Tabel 4.9}

Uji Normalitas Skor Pre-test Kemampuan Berfikir Kritis Kelas Kontrol

\begin{tabular}{|c|r|r|r|r|r|c|}
\hline \multirow{2}{*}{} & \multicolumn{3}{|c|}{ Kolmogorov-Smirnov ${ }^{\mathrm{a}}$} & \multicolumn{3}{|c|}{ Shapiro-Wilk } \\
\cline { 2 - 7 } & Statistic & \multicolumn{1}{c|}{ df } & \multicolumn{1}{c|}{ Sig. } & Statistic & \multicolumn{1}{c|}{ df } & \multicolumn{1}{c|}{ Sig. } \\
\hline pretest kontrol & .146 & 25 & .177 & .957 & 25 & .350 \\
\hline
\end{tabular}

Tabel 4.9 menunjukkan bahwa skor pre-test kemampuan berfikir kritis siswa kelas kontrol untuk uji normalitas Kolmogorof-Smirnov memiliki skor P-value $(\mathrm{Sig})=0,177>0.05$ sehingga $\mathrm{H}_{0}$ diterima pada taraf signifikansi = 0.05 . Artinya, skor pre-test kemampuan berfikir kritis kelas ekperimen ini berdistribusi normal.

\section{c. Uji normalitas data skor postes}

kemampuan berfikir kritis di kelas kontrol Adapun bentuk Hipotesis Uji Normalitas Skor postes Kemampuan Berfikir kritis Siswa Kelas Eksperimen :

$\mathrm{H}_{0}$ : Skor post-test kemampuan berfikir kritissiswa kelas control berdistribusi normal. 
$\mathrm{H}_{1}$ : Skor post-test kemampuan berfikir kritissiswa kelas kontrol tidak berdistribusi normal.

Kriteria yang digunakan untuk menolak dan menerima $\mathrm{H}_{0}$ berdasarkan $\mathrm{P}$-value adalah $\mathrm{H}_{0}$ ditolak jika nilai signifikansi $\mathrm{P}$-value $<\alpha$ (taraf signifikansi 0,05) dan $\mathrm{H}_{0}$ diterima jika nilai signifikansi $\mathrm{P}$-value $\geq \alpha$. Dari hasil perhitungan dengan menggunakan software SPSS 23.0 for windows, diperoleh hasil uji normalitas pada tabel 4.9 sebagai berikut:

Tabel 4.10

Uji Normalitas Skor Postes Kemampuan Berfikir Kritis Kelas Kontrol

\begin{tabular}{|l|r|r|r|r|r|c|}
\hline \multirow{2}{*}{} & \multicolumn{3}{|c|}{ Kolmogorov-Smirnov $^{\text {a }}$} & \multicolumn{3}{c|}{ Shapiro-Wilk } \\
\cline { 2 - 7 } & Statistic & \multicolumn{1}{c|}{ df } & \multicolumn{1}{c|}{ Sig. } & Statistic & \multicolumn{1}{c|}{ df } & \multicolumn{1}{c|}{ Sig. } \\
\hline posttest kontrol & .104 & 26 & $.200^{\star}$ & .983 & 26 & .926 \\
\hline
\end{tabular}

Tabel 4.10 menunjukkan bahwa skor post-test kemampuan berfikir kritis siswa kelas eksperimen untuk uji normalitas Kolmogorof-Smirnov memiliki skor P-value $(\mathrm{Sig})=0,20>0.05$ sehingga $\mathrm{H}_{0}$ diterima pada taraf signifikansi = 0.05. Artinya, skor post-test kemampuan berfikir kritis kelas eksperimen ini berdistribusi normal. Berdasarkan hasil uji normalitas KolmogorofSmirnov kedua skor kemampuan berfikir kritis pada kelas kontrol yang berdistribusi normal. Sehingga pengolahan data dapat dilanjutkan dengan uji homogenitas.

\section{d. Uji homogenitas data skor pretes dan postes kemampuan berfikir kritis di kelas kontrol}

Uji homogenitas data skor pretes dan postes kemampuan berfikir kritis di kelas ekperimen dilakukan karena skor kedua skor berdistribusi normal. Ada pun bentuk hipotesis dari uji homogenitas data ini adalah sebagai berikut:

$\mathrm{H}_{0}$ : Skor pretest dan potes kemampuan berfikir kritis kelas kontrol bervariansi homogen.

$\mathrm{H}_{1}$ : Skor pretest dan potes kemampuan berfikir kritis kelas kontrol bervariansi tidak homogen.

$\mathrm{H}_{0}$ ditolak jika nilai signifikansi $\mathrm{P}$-value $<\alpha$ (taraf signifikansi). $\mathrm{H}_{0}$ diterima jika nilai signifikansi $\mathrm{P}$ value $\geq \alpha$ (taraf signifikansi). Data hasil uji homogenitas menggunakan software SPSS 23.0 for windows dengan uji Levene dapat dilihat pada tabel 4.5 berikut ini:
Tabel 4.11

Uji Homogenitas Skor Pre-test Kemampuan Berfikir kritis Kelas Eksperimen dan Kelas Kontrol

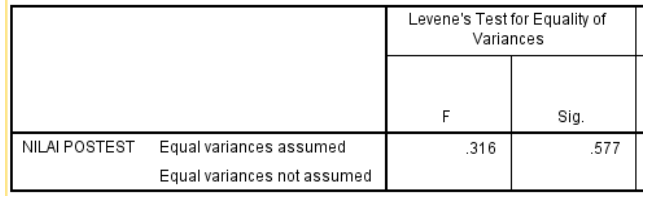

Tabel 4.11 menunjukkan bahwa hasil uji homogenitas skor pre-test kemampuan berfikir kritis siswa kedua kelas memiliki P-value (Sig) $0,577 \geq \alpha=0,05$ dengan demikian $\mathrm{H}_{0}$ ditolak pada taraf signifikansi $\alpha=0,05$. Artinya, skor pre-test dan postes kemampuan berfikir kritis kelas kontrol bervariansi homogen.

e. Uji perbedaan dua rata-rata data skor pretes dan postes kemampuan berfikir kritis di kelas kontrol

Selanjutnya, dilakukan analisis data uji perbedaan rata-rata karena data kedua skor pada kelas kontrol berdistribusi normal dan bervariansi homogen, maka digunakan uji hipotesis dengan uji-t (Paired-sample t test) dengan asumsi kedua varians homogen (Equal Variance Assumed). Untuk menguji perbedaan dua rata-rata masingmasing skor pretes dan postes di kelas kontrol kemampuan berfikir kritis siswa dilakukan dengan menggunakan bantuan program komputer software SPSS 23.0 for windows. Hipotesis yang digunakan dalam uji-t adalah sebagai berikut:

$\mathrm{H}_{0}$ : Tidak terdapat perbedaan rata-rata skor pre-test dan postes kemampuan berfikir kritis kelas kontrol .

$\mathrm{H}_{1}$ : Terdapat perbedaan yang signifikan skor pre-test dan postes kemampuan berfikir kritis kelas kontrol.

$\mathrm{H}_{0}$ ditolak jika nilai signifikansi $\mathrm{P}$-value < $\alpha$ (taraf signifikansi). $\mathrm{H}_{0}$ diterima jika nilai signifikansi $\mathrm{P}$-value $\geq \alpha$ (taraf signifikansi). Ada pun hasil uji-t ditunjukkan pada tabel 4.15 berikut ini:

Tabel 4.12

Analisi Uji-T Skor Pre-test dan Postes Kemampuan berfikir kritis kelas kontrol

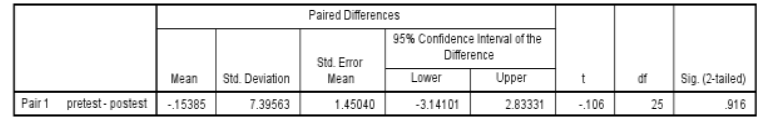

Tabel 4.12 menunjukkan hasil uji-t dengan skor P-value (Sig. 2 tailed) $=0,975$ pada taraf signifikansi $\alpha=0,05$ karena yang diuji satu arah sehingga 0,916 dibagi 2 hasilnya $=0,458>0,05=$ $\alpha$, kondisi demikian $\mathrm{H}_{0}$ diterima artinya, tidak terdapat perbedaan yang signifikan skor pre-test 
dan postes kemampuan kemampuan berfikir kritis siswa di kelas kontrol.

\section{Gain Kelas Ekperimen dan Kelas Kontrol}

Berdasarkan rumusan masalah nomer 3, hipotesis pada penelitian yang harus diuji adalah "terdapat peningkatan kemampuan berpikir kritis pada siswa yang pembelajarannya menggunakan model Pembelajaran kontekstual lebih tinggi daripada siswa yang pembelajarannya menggunakan pembelajaran konvensional". Skor pretes kemampuan berfikir kritis diperoleh dari tes yang diberikan sebelum pembelajaran diterapkan di kelas eksperimen dan kelas kontrol. Analisis uji kesamaan rataan skor gain kemampuan berfikir kritis antara siswa di kelas kontrol dan kelas eksperimen bertujuan untuk memperlihatkan bahwa terdapat peningkatan atau tidak. Sebelum melakukan uji dua rata-rata, terlebih dahulu dilakukan uji normalitas dan homogenitas variansi. Adapun langkah-langkah pengujian hipotesis ini adalah sebagai berikut:

a. Analisis Data Gain Skor Kemampuan Berfikir Kritis Siswa di Kelas Eksperimen dan Kelas Kontrol

Statistik deskriptif skor gain kemampuan berfikir kritis siswa kelas kontrol dan eksperimen disajikan dalam tabel 4.13 dan tabel 4.14 berikut ini:

Tabel 4.13

Statistik Deskriptif Skor Gain Kemampuan Berfikir Kritis Siswa Kelas Kontrol

\begin{tabular}{|c|c|c|c|c|}
\hline & & & Statistic & Std. Error \\
\hline \multirow[t]{13}{*}{ NGAIN KONTROL } & Mean & & 3.5383 & 3.57910 \\
\hline & \multirow{2}{*}{$\begin{array}{l}95 \% \text { Confidence Interval for } \\
\text { Mean }\end{array}$} & Lower Bound & -3.8329 & \\
\hline & & Upper Bound & 10.9096 & \\
\hline & $5 \%$ Trimmed Mean & & .0121 & \\
\hline & Median & & .0750 & \\
\hline & Variance & & 333.058 & \\
\hline & Std. Deviation & & 18.24988 & \\
\hline & Minimum & & -1.31 & \\
\hline & Maximum & & 93.00 & \\
\hline & Range & & 94.31 & \\
\hline & Interquartile Range & & .31 & \\
\hline & Skewness & & 5.096 & 456 \\
\hline & Kurtosis & & 25.979 & .887 \\
\hline
\end{tabular}

Tabel 4.14

Statistik Deskriptif Skor Gain Kemampuan Berfikir Kritis Siswa Kelas Eksperimen

\begin{tabular}{|c|c|c|c|c|}
\hline & & & Statistic & Std. Error \\
\hline \multirow[t]{13}{*}{ NGAIN EKSPERIMEN } & Mean & & 4990 & .04438 \\
\hline & \multirow{2}{*}{$\begin{array}{l}95 \% \text { Confidence Interval for } \\
\text { Mean }\end{array}$} & Lower Bound & 4076 & \\
\hline & & Upper Bound & .5904 & \\
\hline & 5\% Trimmed Mean & & 4929 & \\
\hline & Median & & 4962 & \\
\hline & Variance & & .051 & \\
\hline & Std. Deviation & & .22631 & \\
\hline & Minimum & & .15 & \\
\hline & Maximum & & 1.00 & \\
\hline & Range & & .85 & \\
\hline & Interquartile Range & & .40 & \\
\hline & Skewness & & 283 & 456 \\
\hline & Kurtosis & & -.863 & .887 \\
\hline
\end{tabular}

Berdasarkan data pada tabel 4.13 dan tabel 4.14 jumlah sampel kedua kelas adalah 26 siswa untuk kelas eksperimen dan 25 siswa untuk kelas kontrol. Pada rata-rata skor gain kemampuan berfikir kritis siswa kelas eksperimen memiliki nilai rata-rata gain 0,50 dan lebih tinggi dari ratarata gain kelas kontrol yang hanya memiliki nilai rata-rata 0,03 Selisih rata-rata antara kedua kelas adalah 0,47. Skor gain maksimal di kelas kontrol adalah 1,00, sedangkan skor gain maksimal di kelas eksperimen adalah 0,93 . Skor gain minimal di kelas kontrol adalah -1,31, sedangkan skor gain minimal di kelas eksperimen adalah 0,15. Perbedaan skor gain antara kelas eksperimen dan kelas kontrol ini sudah tergolong sedang, sehingga kedua kelas memiliki skor gain kemampuan berfikir kritis siswa awal yang relatif berbeda. Pengolahan data skor gain kemampuan berfikir kritis ini dimulai dengan cara melakukan uji normalitas pada kelas eksperimen dan kelas kontrol. Uji normalitas skor gain kemampuan berfikir kritis siswa kedua kelas menggunakan uji Kolmogorov-Smirnov dengan tujuan untuk mengetahui apakah data dari masing-masing sampel itu berdistribusi normal atau tidak. Uji normalitas ini menggunakan bantuan software SPSS 23.0 for windows.

b. Uji Normalitas Data Skor Gain Kemampuan Berfikir Kritis Siswa di Kelas Eksperimen

Ada pun bentuk hipotesis uji normalitas skor gain kemampuan berfikir kritis siswa kelas eksperimen $\mathrm{H}_{0}$ : Skor gain kemampuan berfikir kritis siswa kelas eksperimen berdistribusi normal.

$\mathrm{H}_{1}$ : Skor gain kemampuan berfikir kritis siswa kelas eksperimen tidak berdistribusi normal.

Kriteria yang digunakan untuk menolak dan menerima $\mathrm{H}_{0}$ berdasarkan $\mathrm{P}$-value adalah $\mathrm{H}_{0}$ ditolak jika nilai signifikansi P-value $<\alpha$ (taraf signifikansi 0,05) dan $\mathrm{H}_{0}$ diterima jika nilai signifikansi $\mathrm{P}$-value $\geq \alpha$. Dari hasil perhitungan dengan menggunakan software SPSS 23.0 for windows, diperoleh hasil uji normalitas pada tabel 4.15 sebagai berikut:

Tabel 4.15

Uji Normalitas Skor Gain Kemampuan

Berfikir Kritis Siswa Kelas Eksperimen

\begin{tabular}{|c|c|c|c|r|r|c|}
\hline & \multicolumn{3}{|c|}{ Kolmogorov-Smirnov $^{\mathrm{a}}$} & \multicolumn{3}{c|}{ Shapiro-Wilk } \\
\cline { 2 - 7 } & Statistic & \multicolumn{1}{c|}{ df } & \multicolumn{1}{c|}{ Sig. } & Statistic & \multicolumn{1}{c|}{ df } & \multicolumn{1}{c|}{ Sig. } \\
\hline NGAIN EKSPERIMEN & .168 & 26 & .057 & .947 & 26 & .197 \\
\hline
\end{tabular}

Tabel 4.15 menunjukkan bahwa skor gain kemampuan berfikir kritis siswa kelas eksperimen untuk uji normalitas Kolmogorof-Smirnov 
memiliki skor P-value $(\mathrm{Sig})=0,057>0.05$ sedemikian sehingga $\mathrm{H}_{0}$ diterima pada taraf signifikansi $=0.05$. Artinya, skor gain kemampuan berfikir kritis kelas ekperimen ini berdistribusi normal.

\section{c. Uji Normalitas Data Skor Gain Kemampuan Berfikir Kritis Siswa di Kelas Kontrol}

Ada pun bentuk hipotesis uji normalitas skor gain kemampuan berfikir kritis siswa kelas kontrol :

$\mathrm{H}_{0}$ : Skor gain kemampuan berfikir kritis siswa kelas kontrol berdistribusi normal.

$\mathrm{H}_{1}$ : Skor gain kemampuan berfikir kritis siswa kelas kontrol tidak berdistribusi normal.

Kriteria yang digunakan untuk menolak dan menerima $\mathrm{H}_{0}$ berdasarkan $\mathrm{P}$-value adalah $\mathrm{H}_{0}$ ditolak jika nilai signifikansi P-value $<\alpha$ (taraf signifikansi 0,05) dan $\mathrm{H}_{0}$ diterima jika nilai signifikansi $\mathrm{P}$-value $\geq \alpha$. Dari hasil perhitungan dengan menggunakan software SPSS 23.0 for windows, diperoleh hasil uji normalitas pada tabel 4.35 sebagai berikut:

Tabel 4.15

Uji Normalitas Skor Gain Kemampuan Berfikir Kritis Siswa Kelas Kontrol

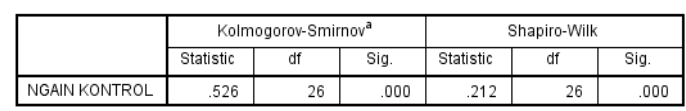

Tabel 4.15 menunjukkan bahwa skor gain kemampuan berfikir kritis siswa kelas kontrol. Ada pun hasil uji normalitas skor gain kemampuan berfikir kritis siswa kelas kontrol untuk uji normalitas Kolmogorof-Smirnov memiliki skor P-value $(\mathrm{Sig})=0,00<0.05$ sedemikian sehingga $\mathrm{H}_{0}$ ditolak pada taraf signifikansi $=0.05$. Artinya, skor gain kemampuan berfikir kritis siswa kelas kontrol ini berdistribusi tidak normal.

Berdasarkan hasil uji normalitas KolmogorofSmirnov kelas eksperimen memiliki skor gain kemampuan berfikir kritis siswa yang berdistribusi normal, sedangkan kelas kontrol memiliki skor gain kemampuan berfikir kritis siswa yang berdistribusi tidak normal. Sehingga pengolahan data dapat dilanjutkan dengan uji non parametric Mann Whitney.

\section{d. Uji Perbedaan Dua Rata-Rata Data Skor Gain Kemampuan Berfikir Kritis Siswa}

Pada penelitian ini karena kedua kelas memiliki skor gain kemampuan berfikir kritis siswa yang berdistribusi tidak normal, maka pada uji perbedaan rata-rata yang menggunakan uji non parametrik mann-Whitney dengan taraf signifikansi $\alpha=0,05$ yang dilakukan dengan menggunakan bantuan program SPSS 23.0 for windows. Ada pun hipotesis yang digunakan adalah sebgai berikut:

$\mathrm{H}_{0}$ : Tidak terdapat perbedaan skor gain kemampuan berfikir kritis siswa kelas eksperimen dan kelas kontrol.

$\mathrm{H}_{1}$ : Terdapat perbedaan yang signifikan skor gain kemampuan berfikir kritis siswa kelas eksperimen dan kelas kontrol.

$\mathrm{H}_{0}$ ditolak jika nilai signifikansi $\mathrm{P}$-value $<\alpha$ (taraf signifikansi). $\mathrm{H}_{0}$ diterima jika nilai signifikansi Pvalue $\geq \alpha$ (taraf signifikansi). Ada pun hasil uji-t ditunjukkan pada tabel 4.36 berikut ini:

\section{Tabel 4.36}

Analisis Uji Mann Whitney Skor Gain Kemampuan Berfikir Kritis Siswa Kelas Eksperimen Dan Kontrol

\begin{tabular}{|l|r|}
\hline & \multicolumn{1}{|c|}{$\begin{array}{c}\text { NILAI } \\
\text { POSTEST }\end{array}$} \\
\hline Mann-Whitney U & 23.000 \\
Wilcoxon W & 348.000 \\
Z & -5.692 \\
Asymp. Sig. (2-tailed) & .000 \\
\hline
\end{tabular}

Tabel 4.36 menunjukkan hasil Mann Whitney perbedaan rata-rata gain kemampuan berfikir kritis siswa kelas eksperimen dan kelas kontrol dengan taraf signifikansi $\alpha=0,05$ dengan skor Pvalue (Sig. 2 tailed) $=0,000$ pada taraf signifikansi $\alpha=0,05$ karena yang diuji satu arah sehingga 0,000 dibagi 2 hasilnya $=0,000<0,05=$ $\alpha$, kondisi demikian $\mathrm{H}_{0}$ ditolak artinya, terdapat perbedaan yang signifikan skor gain kemampuan berfikir kritis siswa kelas eksperimen dan kelas kontrol.

\section{SIMPULAN}

Berdasarkan hasil analisis dan pembahasan yang telah dipaparkan pada Bab IV, maka diperoleh kesimpulan sebagai berikut:

1. Peningkatan kemampuan pembelajaran matematika siswa yang mendapatkan pembelajaran dengan pendekatan pembelajaran kontekstual lebih meningkat dibandingkan dengan siswa yang mendapatkan pembelajaran konvensional.

2. Peningkatan kemampuan berfikir kritis siswa yang mendapatkan pembelajaran dengan pendekatan pembelajaran kontekstual lebih baik dibandingkan dengan siswa yang mendapatkan pembelajaran konvensional. 


\section{DAFTAR PUSTAKA}

Alwasilah, C. (2006). Contextual Teaching And Learning. Bandung : Mizan Learning Center (MLC).

Arikunto, Suharsimi (2010), Prosedur Penelitian Suatu Pendekatan Praktik

Cahyono, Budi. (2015). Korelasi Pemecahan Masalah dan Indikator Berfikir Kritis. Jurnal Pendidikan MIPA Vol 5, N0 1 (2015): Jurnal Pendidikan MIPA page, 1524. Publisher : Sain and Technology Faculty, Walisongo State Islamic University.

Depdiknas Dirjen Pendasmen. (2002). Pendekatan Kontekstual . Jakarta

Depdiknas Dirjen Pendasmen. (2002). Manajemen Peningkatan Mutu sekolah buku 5Pembelajaran dan Pengajaran Kontekstual. Jakarta

Fisher, Alec (2009). Berpikir Kritis Sebuah Penghantar. Jakarta: Erlangga

Kusmaryono. (2011). Keefektifan Pembelajaran Kontekstual Berorientasi Penemuan Berbantuan CD Pembelajaran Dan LKS Pada Materi Bilangan Bulat Di Sekolah Dasar. Makalah Majalah Ilmiah Sultan Agung Vol 50, No 126 (2012). Jurnal Majalah Ilmiah Sultan Agung, Des 2011Feb 2012. Publisher : Universitas Islam Sultan Agung.

Meltzer. (2002). The relationship Between Mathematics Preparation and Conceptual Learning Gain in Physics : A Posible "Hidden Variable in Diagnostic Pretest Scores". American Journal Physic.

Prasetyo,B.,dan Lina Miftahul Jannah (2005:160). Metode penelitian kuantitatif: teori dan aplikasi, Jakarta, PT Raja Grafindo Persada.

Puspadewi, dkk. (2014). Peningkatan Kemampuan Berpikir Kritis Melalui Pendekatan Pembelajaran Kooperatif Tipe Student Teams Achievement Division Pada Mata Pelajaran Pkn Siswa Kelas V Sd N 2 Blahbatuh. e-Jurnal Mimbar PGSD Universitas Pendidikan Ganesha Jurusan PGSD Vol: 2 No: 1 Tahun: 2014.

Redhana, I Wayan. (2003) Meningkatkan Keterampilan Berpikir Kritis Siswa Melalui Pembelajaran Kooperatif Dengan Strategi Pemecahan Masalah. Jurnal Pendidikan Dan Pengajaran XXXVI. II: 11-21.
Saeed, Sitwat, dan David Zyngier. (2012). How Motivation Influences Student Engagement: A Qualitative Case Study. Journal Of Education And Learning. Vol. 1 No. 2

Santoso, Singgih (2009), Panduan Lengkap Menguasai Statistik dengan SPSS 16.

Jakarta: Elex Media Komputindo.

Sudjana, (2005), Metoda Statistika.Bandung: PT. Mizan Pustaka.

Sugiyono. (2013). Metode Penelitian Kuantitatif, Kualitatif, dan Kombinasi (Mixed Methods).Bandung: CV. Alfabeta.

Sukardi. (2003). Metodologi penelitian pendidikan kompetensi dan praktiknya. Jakarta : PT. Raja Grafindo Persada. 